\title{
VULNERABILITY AND ADAPTATION ASSESSMENT OF AGRICULTURE TO CLIMATE CHANGE IN EGYPT USING MATHEMATICAL MODELS
}

\author{
El-Malky, M. G. ${ }^{(1)}$; Abdelwahab, M. M. ${ }^{(2)}$; Bryant, C.R. ${ }^{(3)}$ \\ and Tantawi, $\mathrm{S}^{(\mathbf{( 4 )}}$ \\ 1) Institute of Environmental Studies \& Research, Ain Shams University \\ 2) Faculty of Science, Cairo University 3) University of Montreal, Quebec, \\ Canada. 4) Egyptian Environmental Affairs Agency (EEAA), Cairo, Egypt.
}

\begin{abstract}
Agriculture is considered as an essential economic driver in Egypt. It is an issue as a local food source, for international trade, the food industry and fiber manufacturing as well as water and land use. The climate change vulnerability of agriculture can be mainly attributed to parameters of the economy, society and the environment. Climate change will affect agricultural crop yields which consequently impact different food security domains, namely access to food, food supplies stability, food utilization and food production and trade. The aim of this research paper is to undertake an assessment of the impacts of climate change on agricultural crop yields and national sufficiency based on real observations and results obtained by previous research in Egypt. Both Regional Circulation Models (RCM) and Decision Support System for Agro-technology Transfer (DSSAT) have been used to generate climate projections up to 2050. Results indicate that climate model performance varies for different regions or processes under consideration; the Model ECHAM5 gives the best matching results to observations compared with other models. Climate change can exacerbate the food security crises that Egypt already faces, and without an urgent and comprehensive set of adaptation measures, Egypt may experience adverse impacts on more than one strategic crop.
\end{abstract}

Keywords: Climate Change, Global Circulation Models, Regional Circulation Models, mathematical computer models, temperature, Egypt. 
J. Environ. Sci.

Institute of Environmental Studies and Research - Ain Shams University

\section{INTRODUCTION}

Egypt is very sensitive to climate change because it relies for about 95 percent of its fresh water budget on the Nile River (Rosenzweig et al., 2002; World Bank Report, 2007). The Initial and Second National Communication reports (EEAA, 1999, 2010) reported that although Egypt's emissions from Greenhouse Gases is less than $1 \%$ of total global emissions, it is highly vulnerable to the adverse effects of climate change. A variety of research has highlighted the high sensitivity of the Nile River to temperature and precipitation change (Riebsame, 2005). Agriculture in Egypt is expected to suffer adverse impacts due to heat waves, which will affect the crop productivity of more than one strategic crop. These effects are intensifying because agriculture and agro-ecological systems are classified as the main economic drivers of Egypt (Riebsame, 2005). Additional research was conducted to simulate and assess climate change on crop yields and crop water requirements under different agro-climatological zones in Egypt (Abou Hadid, 2006; El-Marsafawy et al., 2007). The studies projected a decrease in food production in Egypt by about 11-19\% by 2050 .

Adaptation to climate change can modify the projected harshness of food production (Easterling, 2007). Some economic changes (e.g. shifts in planting dates and converting to alternative and available crop mixtures) may balance the negative impacts; but the biggest benefits will likely arise from expensive actions comprising improvement of new crop collections and irrigation (Abou Hadid, 2006). 
Seven Global Circulation Models (GCMs) were examined and compared with observed meteorological data from 1980 to 2010 at eight different locations representing different climate profiles in Egypt. Observed data from previous field experiments were used as inputs to the models. The efficiency of different Regional Climate Models (RCMs) in the downscaling process has been tested to select the best with a suitable GCM in Egypt. This study was carried out by running two RCMs on reanalyzed data at a higher resolution and comparing the results from both with observed data. The study concluded that the RegCM.4 model gives better results than PRECIS when compared with observations. An agricultural model was used to assess crop sensitivity to climate change. The aim of the study is to use models to assess the climate change impacts on some strategic crops (maize, milled rice and wheat) over the long run. Verifications of the model outcomes still need to be calibrated through implementation of more field experiments.

\section{MATERIALS AND METHODS}

\section{A) Selection of Models:}

(i) Climate Models:

- Seven climate models were selected for performance assessment, the list of models comprises (CCSM3, CCSR, ECHAM5, CCCMA, GFDL, CNRM and BCC); a short description of the GCMs is illustrated in Table (1).

- Analysis of time series and three statistical metrics were identified and used, i.e. the correlation coefficient, standard deviation and Root Mean 
Square Error (RMSE). These statistical analytic approaches have been used for two climate variables (precipitation and temperature).

- The model's results were checked and compared separately with field measurements based on its power to emulate detected seasonal patterns of temperature and precipitation over Egypt region over the period 20052015; meteorological data were obtained from the Central Laboratory for Agricultural Climate (CLAC) - Agriculture Research Center (ARC).

- Eight weather stations were selected with high to low agricultural density covering most of the climatic profiles in Egypt.

- The efficiency of a GCM may change depending upon meteorological elements and regions. Typically, GCMs are verified for their power to emulate dimensional patterns of specific meteorological elements and their periodicity (McKendry et al., 1995; Huth, 1997, Nemesova and Kalvova, 1997; Nemesova et al., 1999)

\section{(ii) Agricultural Model:}

The Decision Support System for Agrotechnology Transfer (DSSAT) was selected; this is a software application with crop simulation models for more than 42 crops. The Model was used to assess crop sensitivity; specific major crops were selected based on the obtained results from most previous studies.

\section{B) Identification of time duration and crops}

Time durations of the study were selected using several different criteria. Among those criteria is the crop importance (strategic level of the crop) for a specific region considering the human population [Hunger Importance 
Indicator (HII)]. Maize, milled rice and wheat were selected among the list of strategic crops of Egypt (FAO, 2012).

Table 1: List of selected Global Circulation Models for use in the study

\begin{tabular}{|c|c|c|c|c|c|}
\hline No & $\begin{array}{l}\text { Model ID, } \\
\text { Vintage }\end{array}$ & Sponsor(s), Country & $\begin{array}{c}\text { Atmosphere } \\
\text { Top Resolution } \\
\text { References } \\
\end{array}$ & $\begin{array}{l}\text { Ocean Resolution } \\
\text { Z Coord., Top BC } \\
\text { References } \\
\end{array}$ & $\begin{array}{c}\text { Land } \\
\text { Soil, Plants, Routing } \\
\text { References } \\
\end{array}$ \\
\hline 1 & CCSM3, 2005 & $\begin{array}{l}\text { National Center for Atmospheric } \\
\text { Research, USA }\end{array}$ & $\begin{array}{l}\text { top }=2.2 \mathrm{hPa} \\
\mathrm{T} 85\left(1.4^{\circ} \times 1.4^{\circ}\right) \mathrm{L} 26 \\
\text { (Collins et al., 2004) }\end{array}$ & $\begin{array}{l}0.3^{\circ}-1^{\circ} \times 1^{\circ} \mathrm{L} 40 \\
\text { depth, free surface } \\
\text { (Smith and Gent, } \\
\text { 2002) }\end{array}$ & $\begin{array}{l}\text { layers, canopy, routing } \\
\text { (Oleson et al., 2004; } \\
\text { Branstetter, 2001) }\end{array}$ \\
\hline 2 & $\operatorname{CCSR}, 2004$ & $\begin{array}{l}\text { Center for Climate System Research } \\
\text { (University of Tokyo), National Institute } \\
\text { for Environmental Studies, and Frontier } \\
\text { Research Center for Global Change } \\
\text { JAMSTEC), Japan }\end{array}$ & $\begin{array}{c}\text { top }=40 \mathrm{~km} \\
\text { T106 }\left(\sim 1.1^{\circ} \times 1.1^{\circ}\right) \mathrm{L} 56 \\
(\mathrm{~K}-1 \text { Developers, 2004) }\end{array}$ & $\begin{array}{l}0.2^{\circ} \times 0.3^{\circ} \mathrm{L} 47 \\
\text { sigma/depth, free } \\
\text { surface } \\
\text { (K-1 Developers, } \\
\text { 2004) } \\
\end{array}$ & $\begin{array}{l}\text { layers, canopy, routing } \\
\text { (K-1 Developers, 2004; } \\
\text { Oki and Sud, 1998) }\end{array}$ \\
\hline 3 & $\begin{array}{l}\text { ECHAM5/MPI- } \\
\text { OM, } 2005\end{array}$ & $\begin{array}{l}\text { Max Planck Institute for Meteorology, } \\
\text { Germany }\end{array}$ & $\begin{array}{c}\text { top }=10 \mathrm{hPa} \\
\text { T63 }\left(\sim 1.9^{\circ} \times 1.9^{\circ}\right) \mathrm{L} 31 \\
\text { (Roeckner et al., 2003) }\end{array}$ & $\begin{array}{l}1.5^{\circ} \times 1.5^{\circ} \mathrm{L} 40 \\
\text { depth, free surface } \\
\text { (Marsland et al., } \\
\text { 2003) }\end{array}$ & $\begin{array}{l}\text { bucket, canopy, routing } \\
\text { (Hagemann, 2002; } \\
\text { Hagemann and } \\
\text { Dümenil-Gates, 2001) }\end{array}$ \\
\hline 4 & $\begin{array}{l}\text { CCCMA } \\
\text { (T63), } 2005\end{array}$ & $\begin{array}{l}\text { Canadian Centre for Climate Modelling } \\
\text { and Analysis, Canada }\end{array}$ & $\begin{array}{c}\text { top }=1 \mathrm{hPa} \\
\text { T63 }\left(\sim 1.9^{\circ} \times 1.9^{\circ}\right) \mathrm{L} 31 \\
\text { (McFarlane et al., 1992; } \\
\text { Flato 2005) }\end{array}$ & $\begin{array}{c}0.9^{\circ} \times 1.4^{\circ} \mathrm{L} 29 \\
\text { depth, rigid lid } \\
\text { (Flato and Boer, } \\
\text { 2001; Kim et al., } \\
\text { 2002) }\end{array}$ & $\begin{array}{l}\text { layers, canopy, routing } \\
\text { (Verseghy et al., 1993) }\end{array}$ \\
\hline 5 & $\begin{array}{l}\text { GFDL-CM2.0, } \\
2005\end{array}$ & $\begin{array}{l}\text { U.S. Department of Commerce/National } \\
\text { Oceanic and Atmospheric Administration } \\
\text { (NOAA)/Geophysical Fluid Dynamics } \\
\text { Laboratory (GFDL), USA }\end{array}$ & $\begin{array}{c}\text { top }=3 \mathrm{hPa} \\
2.0^{\circ} \times 2.5^{\circ} \mathrm{L} 24 \\
\text { (GFDL GAMDT, 2004) } \\
\text { with semi-Lagrangian } \\
\text { transports } \\
\end{array}$ & $\begin{array}{c}0.3^{\circ}-1.0^{\circ} \times 1.0^{\circ} \\
\text { depth, free surface } \\
\text { (Gnanadesikan et } \\
\text { al., } \\
\text { 2004) }\end{array}$ & $\begin{array}{l}\text { bucket, canopy, routing } \\
\text { (Milly and Shmakin, } \\
\text { 2002; } \\
\text { GFDL GAMDT, 2004) }\end{array}$ \\
\hline 6 & $\begin{array}{l}\text { CNRM-CM3, } \\
2004\end{array}$ & $\begin{array}{l}\text { Météo-France/Centre National de } \\
\text { Recherches Météorologiques, France }\end{array}$ & $\begin{array}{c}\text { top }=0.05 \mathrm{hPa} \\
\text { T63 }\left(\sim 1.9^{\circ} \times 1.9^{\circ}\right) \mathrm{L} 45 \\
\text { (Déqué et al., 1994) }\end{array}$ & $\begin{array}{c}0.5^{\circ}-2^{\circ} \times 2^{\circ} \mathrm{L} 31 \\
\text { depth, rigid lid } \\
\text { (Madec et al., 1998) }\end{array}$ & $\begin{array}{l}\text { layers, canopy,routing } \\
\text { (Mahfouf et al., 1995; } \\
\text { Douville et al., 1995; Oki } \\
\text { and Sud, 1998) }\end{array}$ \\
\hline 7 & BCC-CMl, 2005 & Beijing Climate Center, China & $\begin{array}{c}\text { top }=25 \mathrm{hPa} \\
\mathrm{T} 63\left(1.9^{\circ} \times 1.9^{\circ}\right) \mathrm{L} 16 \\
\text { (Dong et al., 2000; CSMD, } \\
\text { 2005; Xu et al., 2005) }\end{array}$ & $\begin{array}{l}1.9^{\circ} \times 1.9^{\circ} \mathrm{L} 30 \\
\text { depth, free surface } \\
\text { (Jin et al., 1999) }\end{array}$ & $\begin{array}{l}\text { layers, canopy, routing } \\
\text { (CSMD, 2005) }\end{array}$ \\
\hline
\end{tabular}

\section{RESULTS AND DISCUSSION}

\section{A) Climate Models Results}

A time series analysis validation yields a a good comparison between the models' results and observations; the ECHAM5 GCM data give the best results in relation to observations compared with other models, the comparison between climate change scenarios A1B and A2 for ECHAM5 GCM by RegCM.4 were undertaken in order to choose the best of them for Egypt. It was found that applying the scenario A1B gives good results 
compared with A2. The mean annual cycles of models' simulated temperatures and precipitations were analyzed for the eight stations and compared to observations. The Alexandria station was selected in this study as an example, but the rest of the stations were treated using the same processes.

Figure (1.a) and Figure (1.b) show the annual cycle of the model's mean temperature and precipitation compared with the observation, for temperature, almost all GCMs reproduce quite well the annual cycle except the Chinese model (BCC) which failed to capture the temperature of the winter months, while for precipitation, all models capture the rainy (winter) season with an underestimation for some models and overestimation for others. However, all the models give a false precipitation via the dry (summer) season except the ECHAM5 and GFDL models which capture the characteristic feature of the wet (winter) and dry (summer) seasons.

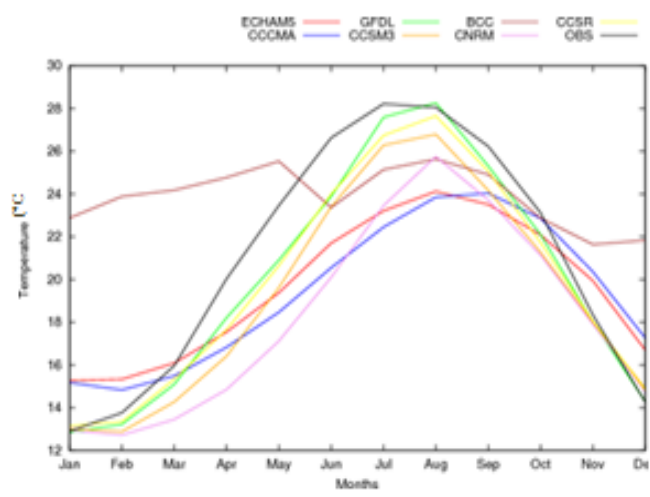

Figure(1.a): The annual cycle of temperature for Alexandria as estimated using 7 models



Figure (1.b): The annual cycle of precipitation for Alexandria as estimated using 7 models 
A comparison between the models and observations with statistical methods such as the root mean square error (RMSE), correlation coefficient, and the mean absolute error (MAE) were processed.

Figure (2.a) shows the correlation for the temperature. It was found that all models have a good correlation in temperature. The correlation has values from 0.85 up to 0.97 except for the BCC model which is anomalous because it gives a very high overestimation especially in the winter months. Figure (2.b) shows the correlation for the precipitation; it was found that Alexandria as a rainy station has a good correlation relative to the other stations.

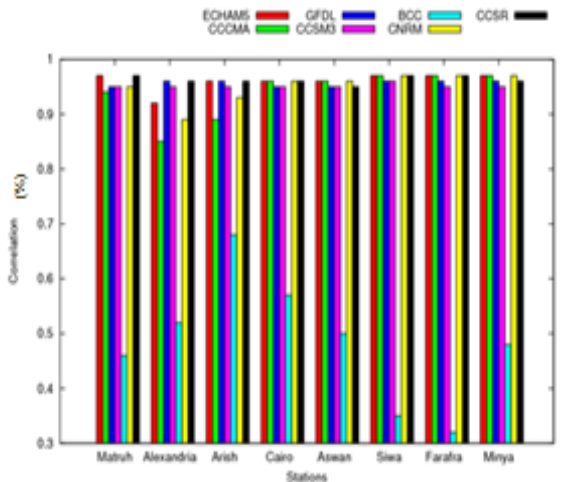

Figure (2.a): The temperature correlation as estimated using 7 models

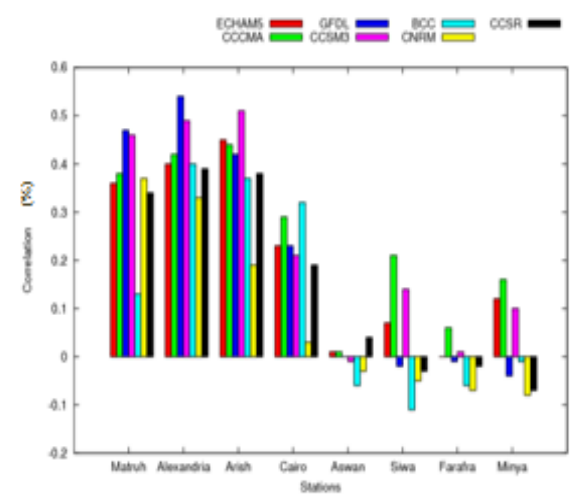

Figure (2.b): The precipitation correlation as estimated using 7 models

The Mean Absolute Error (MAE) test was applied to evaluate the models, for temperature, Figure (3.a) shows that the models vary within a small range except for the BCC model which has the largest MAE, while for precipitation it was found that the error was big. 


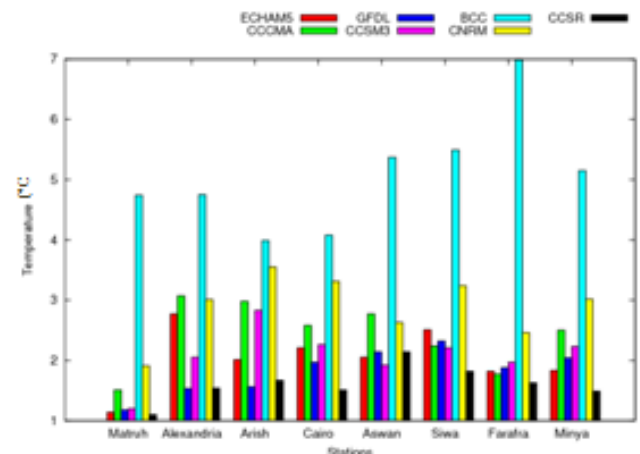

Figure (3.a): The temperature Mean Absolute Error (MAE) as estimated using 7 models



Figure (3.b): The precipitation Mean Absolute Error (MAE) as estimated using 7 models

The Root Mean Square Error (RMSE) test was applied also; it was found that similarly to the results of the MAE, the BCC is the anomalous one with a very high error as shown in Figures (4.a) and (4.b).

The analysis indicates that the ECHAM5 presented the best results; and it was concluded that ECHAM5 is the most suitable model for Egypt



Figure (4.a): The temperature Root Mean Square Error (RMSE) as estimated using 7 models

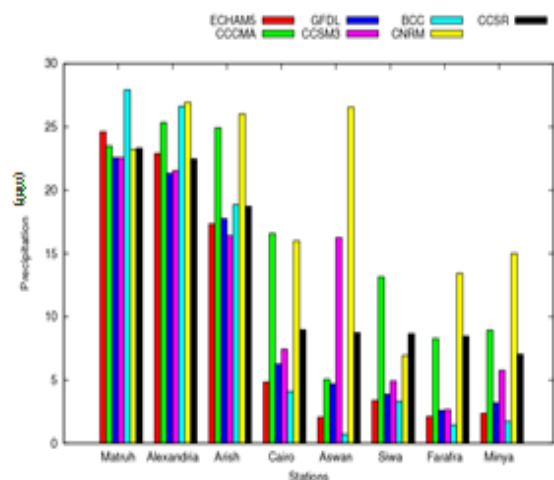

Figure (4.b): The precipitation Root Mean Square Error (RMSE) as estimated using 7 models 


\section{B) Crop Models Results}

The meteorological data (temperature and precipitation) resulting from GCM was used as input for crop models; the crop model outputs concluded that strategic crops are characterized by self-sufficiency under future climate change conditions until 2050 (with no climate change impacts, which is known as the Business-As-Usual scenario), as illustrated in Table (2) and Figure (5), if the cultivated land and crop yield are the same as the current, self-sufficiency with maize, milled rice and wheat which may record $25.6 \%, 83.2 \%$ and $29.7 \%$ compared to $53.6 \%, 160.9 \%$ and $57.4 \%$. Considering increase in population growth rate, water supply shortage and sea level rise and its effect on soil salinization of the North Nile Delta which could decrease the total agriculture area, all these factors will increase the crop sensitivity to climate change in the future. Input data were based on Central Agency for Public Mobilization and Statistics (CAPMS 2013).

Table 2: Estimated rates of self-reliance and self-sufficiency in the main crop yields, with no climate change impacts (Business As Usual ScenarioBAU)

\begin{tabular}{|l|c|c|c|c|c|c|}
\hline \multirow{2}{*}{$\begin{array}{c}\text { Main food } \\
\text { commodities }\end{array}$} & \multicolumn{3}{|c|}{ Crop yield of 2011 } & \multicolumn{3}{c|}{$\begin{array}{c}\text { Crop yield estimates in 2050 (no } \\
\text { climate change impacts) }\end{array}$} \\
\cline { 2 - 7 } & $\begin{array}{c}\text { Prod. } \\
(\mathbf{1 , 0 0 0} \\
\text { tons) }\end{array}$ & $\begin{array}{c}\text { Requirements } \\
(\mathbf{1 , 0 0 0} \text { tons) }\end{array}$ & $\begin{array}{c}\text { Self } \\
\text { suf.(\%) }\end{array}$ & $\begin{array}{c}\text { Prod. } \\
(\mathbf{1 , 0 0 0} \\
\text { tons) }\end{array}$ & $\begin{array}{c}\text { Requireme } \\
\text { nts (1,000 } \\
\text { tons) }\end{array}$ & $\begin{array}{c}\text { Self } \\
\text { suf.(\%) }\end{array}$ \\
\hline \hline Wheat & 8407 & 14650 & 57.4 & 8407 & 28251 & 29.7 \\
\hline Milled rice & 5675 & 3528 & 160.9 & 5675 & 6821 & 83.2 \\
\hline Maize & 6876 & 12827 & 53.6 & 6876 & 26840 & 25.6 \\
\hline Population & \multicolumn{5}{|c|}{83 millions } & \multicolumn{3}{|c|}{158 millions } \\
\hline
\end{tabular}

Resulting outcomes from the current study agree with Fahim et.al (2013) who found that yield declines for strategic crops would be about $25 \%$ by 2030 
because of climate change effects; the results anticipate that the continuous increase in greenhouse gas emissions into the atmosphere because of what mankind's actions induce will dramatically impact crop yields and consequently crop prices. Meanwhile, if Egypt engages in adaptation measures in relation to climate change, as shown in Table (3), and with the increase of cultivated land and production by $10 \%$ (as stated in the Sustainable Agriculture Development Strategy Towards 2030, SADS), then maize, milled rice and wheat self-sufficiency could reach $23 \%, 136.1 \%$ and $40 \%$ by 2050 respectively.

Table 3: Estimated rates of self-reliance and self-sufficiency in the yield of main crops under climate change with and without adaptation actions (Models Simulated)

\begin{tabular}{|c|c|c|c|c|c|c|}
\hline \multirow{2}{*}{$\begin{array}{l}\text { Main food } \\
\text { commodities }\end{array}$} & \multicolumn{3}{|c|}{$\begin{array}{l}2050 \text { estimates with climate change } \\
\text { + no adaptation action }\end{array}$} & \multicolumn{3}{|c|}{$\begin{array}{l}2050 \text { estimates with climate change } \\
+ \text { adaptation action }\end{array}$} \\
\hline & $\begin{array}{c}\text { Prod. } \\
(\mathbf{1 , 0 0 0} \\
\text { tons })\end{array}$ & $\begin{array}{l}\text { Requirements } \\
(1,000 \text { tons })\end{array}$ & $\begin{array}{c}\text { Self } \\
\text { suf. }(\%)\end{array}$ & $\begin{array}{c}\text { Prod. } \\
(1,000 \\
\text { tons })\end{array}$ & $\begin{array}{l}\text { Requirements } \\
(1,000 \text { tons })\end{array}$ & $\begin{array}{c}\text { Self } \\
\text { suf. }(\%)\end{array}$ \\
\hline Wheat & 7535.8 & 28251 & 26.7 & 11303.6 & 28251 & 40 \\
\hline Milled rice & 6078.3 & 6821 & 89.1 & 8576.3 & 6821 & 136.1 \\
\hline Maize & 5766.4 & 26840 & 21.5 & 6174.6 & 26840 & 23 \\
\hline Population & \multicolumn{3}{|c|}{158 millions } & \multicolumn{3}{|c|}{158 millions } \\
\hline
\end{tabular}

The resulting outcomes from the current study correspond to a considerable degree with results of some previous studies (Hassanien et.al, 2007; Abolmaaty et al., 2010; Yones et al.,2011; Fahim et al., 2013), while being different in terms of the level of self-sufficiency of some strategic crops in Egypt under a "no adaptation action" as the continuous increase in national population adds additional burden to climate change's adverse effects and it 
can be expected to decrease the level of self-sufficiency of strategic crops under study to lower than 3 to $5 \%$.



Figure (5): Changing in the main crop yield self-sufficient in Egypt up to 2050 under different scenarios.

\section{C) Climate change effects on selected strategic crops in Egypt}

The crop model DSSAT and other RCM models were processed to project climate change effects on selected crop yields; also some previous field studies have predicted production decreases in the major crops in Egypt as shown in Table (4) and Table (5). 
Table 4: Change in major crop yield production in Egypt by the year 2050 due to climate change.

\begin{tabular}{|c|c|c|c|c|}
\hline & & \multicolumn{3}{|c|}{ Crops } \\
\hline & Item & Maize & Rice & Wheat \\
\hline \hline \multirow{3}{*}{ Current } & Yield (t/fed) & 3.6 & 4.3 & 2.9 \\
\cline { 2 - 5 } & Area (Mfed) & 2.0 & 1.9 & 3.1 \\
\cline { 2 - 5 } & Total Yield (Mt) & 6.6 & 7.6 & 8.4 \\
\hline \multirow{2}{*}{ Projected } & Change (\%) & -23.4 & -15.8 & -19.8 \\
\cline { 2 - 5 } & Yield Deficit (Mt) & -1.8 & -1.2 & -1.6 \\
\hline \hline
\end{tabular}

Resulted outcomes from the current study agree with Fahim et.al. (2013) who found that changes in crop productivity are mainly related to the projected increase in temperature, which negatively affect cereal filling time and have significant effects on the essential flowering stage, and consequently impact the quality and yield of the crop. In addition, the current study shows that crop-water stress under projected threats due to the projected yearly deficiency of the Nile water budget because of dam construction in the upper areas of the Nile Basin will be other factors causing productivity reduction under climate change. Among the results of the DSSAT crop model, it was noted that climate change effects on the crop yield of wheat because of increasing temperature will reduce the length of the crop growing period and negatively affect the yield.

Hassanein et al. (2012) showed that for the scenario of temperature increasing by $+1.5^{\circ} \mathrm{C}$, the model predicted that a decrease in cereal crop yield would be in the rage of $12 \%$ at Sakha, $9 \%$ at Sids and $11 \%$ at Shandaweel. While for the scenario of $+3.5^{\circ} \mathrm{C}$ the cereal crop yield would be reduced by about $27 \%$ at both the Sakha and Sids locations, and by about $31 \%$ at the 
Shandaweel location. The results of the current study agree with Hassanein et al. (2012) and added that a high probability in the future with an accelerating growing cycle, the wheat crop yield could be decreased at the three locations, particularly under the $+3.5^{\circ} \mathrm{C}$ scenario, which implies earlier cultivation and specific agricultural practices.

Table 5: Projected changes in crop production of some major crops in Egypt under climate change conditions

\begin{tabular}{|c|c|c|l|}
\hline \multirow{2}{*}{ Crop } & \multicolumn{2}{|c|}{ Change \% } & \multirow{2}{*}{ Reference } \\
\cline { 2 - 3 } & $\mathbf{2 0 5 0 s}$ & $\mathbf{2 1 0 0 s}$ & \\
\hline \hline Cotton & $\mathbf{+ 1 7 \%}$ & $\mathbf{+ 3 1 \%}$ & Eid et al., 1997a \\
\hline Maize & $\mathbf{- 1 9 \%}$ & & Eid et al., 1997b \\
\hline Maize & $\mathbf{- 1 4 \%}$ & $\mathbf{- 2 0 \%}$ & Hassanien and Medany 2007 \\
\hline Potato & $\mathbf{- 0 . 9}$ to $-\mathbf{2 . 3 \%}$ & $\mathbf{+ 0 . 2}$ to $+\mathbf{2 . 3} \%$ & Medany and Hassanein 2006 \\
\hline Rice & $\mathbf{- 1 1 \%}$ & & Eid and El-Marsafawy 2002 \\
\hline Soybeans & $\mathbf{- 2 8 \%}$ & & Eid and El-Marsafawy 2002 \\
\hline
\end{tabular}

\section{CONCLUSION AND RECOMMENDATIONS}

The potential decreases in food production until 2050 are not significantly small. Strengthening agricultural research and experiments under different climatic circumstances to reach resilient agricultural ecosystems, and expanding the cultivated area are priorities. Until 2050, the most serious and widespread agricultural and food security problems related to climate change are likely to arise from the impact of climate variation, and not from progressive climate change, although the latter will be important where it compounds existing agro-climate constraints.

Policies for agricultural development will need to emphasize the importance of improving not just the production capacity of agricultural ecosystems but also their diversity and resilience. 
It's recommended that future studies take into consideration the assessment of the on-farm irrigation management, cultivation dates, cropping patterns and risk assessment tools to identify agricultural vulnerability and adaptation in Egypt.

\section{REFERENCE}

Abolmaaty S.M.; M.K. Hassanein; A.A. Khalil and A.F Abou-Hadi., (2010): Impact of Climate Changes in Egypt on Degree Day's Units and Generation Number for Tomato Leaf miner Moth Tuta absoluta, (Meyrick) (Lepidoptera gelechiidae), Nature and Science 8(11) 122-129.

Abou Hadid A. F., (2006): Assessment of impacts, adaptation and vulnerability to climate change in North Africa: Food production and water resources. A final report: Assessments of Impacts and Adaptations to Climate Change (AIACC), Project No.AF90 (2006).

Branstetter, M.L., (2001): Development of a Parallel River Transport Algorithm and Application to Climate Studies. PhD Dissertation, University of Texas, Austin, TX.

CAPMS, (2013): Annual report of the Central Agency for Public Mobilization and Statistics.

Collins, W.D., Rasch, P.J., Boville, B.A. Hack, J.J, McCaa, J.R., Williamson, D.L. Kiehl, J.T. and Briegleb, B., (2004): Description of the NCAR Community Atmosphere Model (CAM3.0). Technical Note TN-464+STR, National Center for Atmospheric Research, Boulder, CO, $214 \mathrm{pp}$

CSMD (Climate System Modeling Division), (2005): An introduction to the fi rst general operational climate model at the National Climate Center. Advances in Climate System Modeling, 1, National Climate Center, China Meteorological Administration, 14 pp.

Déqué, M., C. Dreveton, A. Braun, and D. Cariolle, (1994): The ARPEGE/ IFS atmosphere model: A contribution to the French community climate modeling. Clim. Dyn., 10, 249-266. 
Dong, M., Wu, T., and Wang. Z., (2000): Developments and implications of the atmospheric general circulation model. In: Investigations on the Model System of the Short-Term Climate Predictions, China Meteorological Press, Beijing, China, pp. 63-69 (in Chinese).

Douville, H., J.-F. Royer, and J.-F. Mahfouf, (1995): A new snow parameterization for the Meteo-France climate model. Clim. Dyn., $12,21-35$.

Easterling W., (2007): Impacts, Adaptation and Vulnerability. Contribution of Working Group II to the Fourth Assessment Report of the Intergovernmental Panel on Climate Change (Cambridge Univ. Press, Cambridge, pp. 273-313.

EEAA, (1999): "The Arab Republic of Egypt: Initial national communication on climate change under the United Nations Framework Convention on Climate Change," ed: Egyptian Environmental Affairs Agency.

EEAA, (2010): "Egypt second national communication under the United Nations Framework Convention on Climate Change," ed: Egyptian Environmental Affairs Agency (EEAA).

Eid H. M. and El-Marsafawy, S. M., (2002):.Adaptation to climate change in Egyptian Agriculture and water resources. $3^{\text {rd }}$ Int. Symposium on Sustainable Agro-environmental Systems: New Technologies and Applications (AGRON 2002), Egypt, 26-29 October

Eid H. M.; El-Marsafawy, S. M.; Salib, A.Y. and Ali, M. A., (1997a): Vulnerability of Egyptian cotton productivity to climate change, Meteorology and Environmental Cases Conf., Egypt, 2-6 March.

Eid H. M.; El-Marsafawy S. M.; Ainer, N.G.; El-Mowelhi N.M. and ElKholi, O., (1997b): Vulnerability and adaptation to climate change in maize crop. Meteorology \& Environmental Cases Conference, Cairo, Egypt, 2-6 March.

El-Marsafawy M. Samia,( 2007): Impact of climate change on sunflower crop production in Egypt. Egypt J. Agric. Res., 85 (5), pp 200.

Fahim M. A.; M.K. Hassanein; A. A. Khalil and A.F. Abou Hadid, (2013): Climate Change Adaptation Needs for Food Security in Egypt. Nature and Science; pp 111.

FAO (2012): Economic growth is necessary but not sufficient to accelerate reduction of hunger and malnutrition. The state of food insecurity in the world, FAO, Rome 2012. pp 65. 
Flato, G.M., (2005): The Third Generation Coupled Global Climate Model (CGCM3) (and included links to the description of the AGCM3 atmospheric model).

Flato, G.M., and G.J. Boer, (2001): Warming asymmetry in climate change simulations. Geophys. Res. Lett., 28, 195-198.

GFDL GAMDT (The GFDL Global Atmospheric Model Development Team), (2004): The new GFDL global atmosphere and land model AM2- LM2: Evaluation with prescribed SST simulations. J. Clim., 17, 4641- 4673.

Gnanadesikan, A., Dixon, K. W. , Griffies, S. M. , Balaji, V. and Beesley, J. A., (2004): GFDL's CM2 global coupled climate models-Part 2:The baseline ocean simulation. J. Clim.,19, 675-697.

Hagemann, S., (2002): An Improved Land Surface Parameter Dataset for Global and Regional Climate Models. Max Planck Institute for Meteorology Report 162, MPI for Meteorology, Hamburg, Germany, $21 \mathrm{pp}$.

Hagemann, S., and L. Dümenil-Gates, (2001): Validation of the hydrological cycle of ECMWF and NCEP reanalyses using the MPI hydrological discharge model. J. Geophys. Res., 106, 1503-1510.

Hassanein M. K.; M. Elsayed and A.A. Khalil (2012): Impacts of Sowing Date, Cultivar, Irrigation Regimes and Location on Bread Wheat Production in Egypt under Climate Change Conditions. Nat Sci 2012; 10(12) 141-150.

Hassanien M. K. and Medany, M. A., (2007): The Impact of Climate Change on Production of Maize (Zea Mays L.), Proc. of the international conference on "climate change and their impacts on costal zones and River Deltas", Alexandria-Egypt, 23-25 April.

Huth R (1997): Continental-scale circulation in the UKHI GCM. J Clim 10:1545-1561

Jin, X.Z., X.H. Zhang, and T.J. Zhou, (1999): Fundamental framework and experiments of the third generation of the IAP/LASG World Ocean General Circulation Model. Adv. Atmos. Sci., 16, 197-215.

K-1 Model Developers, (2004): K-1 Coupled Model (MIROC) Description. K-1 Technical Report 1 [Hasumi, H., and S. Emori (eds.)]. Center for Climate System Research, University of Tokyo, Japan, 34 pp. 
Kim, S.-J., G.M. Flato, G.J. Boer, and N.A. McFarlane, (2002): A coupled climate model simulation of the Last Glacial Maximum, Part 1: Transient multi-decadal response. Clim. Dyn., 19, 515-537.

Madec, G., P. Delecluse, M. Imbard, and C. Lévy, (1998): OPA Version 8.1 Ocean General Circulation Model Reference Manual. Notes du Pôle de Modélisation No. 11, Institut Pierre-Simon Laplace, Paris, $91 \mathrm{pp}$.

Mahfouf, J.-F., Manzi, A.O, Noilhan, J. Giordani, H. and DéQué, M., (1995): The land surface scheme ISBA within the Meteo-France climate model ARPEGE. Part 1: Implementation and preliminary results. J. Clim., 8, 2039-2057.

Marsland, S. J., Haak, H., Jungclaus, J. H., Latif, M. and Röske, F. (2003): The Max-Planck-Institute global ocean/sea ice model with orthogonal curvilinear coordinates. Ocean Modeling, 5(2), 91-127.

McFarlane, N.A., G.J. Boer, J.-P. Blanchet, and M. Lazare, (1992): The Canadian Climate Centre second-generation general circulation model and its equilibrium climate. J. Clim., 5, 1013-1044.

McKendry IG, Steyn DG, McBean G (1995): Validation of synoptic circulation patterns simulated by the Canadian Climate Centre. Atmosphere-Ocean 33:809-825

Medany M. A. and Hassanein, M. K., (2006): Assessment of the impact of climate change and adaptation on potato production. Egyptian Journal of Applied Sciences. 21 (11B) 623-638.

Milly, P.C.D., and A.B. Shmakin, (2002): Global modeling of land water and energy balances, Part I: The Land Dynamics (LaD) model. J. Hydrometeorol., 3, 283-299.

Nemesova I, Kalvova J (1997): On the validity of ECHAM-simulated daily extreme temperatures. Studia Geoph Geod 41:396-406.

Nemesova I, Kalvova J, Dubrovsky M (1999): Climate change projections based on GCM-simulated daily data. Studia Geoph Geod 3:201222

Oki, T., and Y.C. Sud, (1998): Design of total runoff integrating pathways (TRIP),A global river channel network. Earth Interactions, 2, 137.

Oleson, K.W., et al., (2004): Technical Description of the Community Land Model (CLM). NCAR Technical Note NCAR/TN-461+STR, National Center for Atmospheric Research, Boulder, CO, 173 pp 
Riebsame W. E. (2005): "Complex River Basins," in As climate changes: international impacts and implications, K. M. Strzepek and J. B. Smith, Eds., ed Cambridge; New York, NY, USA: USEPA, 213 p.

Roeckner, E., et al., (2003): The Atmospheric General Circulation Mode ECHAM5. Part I: Model Description. MPI Report 349, Max Planck Institute for Meteorology, Hamburg, Germany, 127 pp.

Rosenzweig C.; Tubiello F.N.; Goldberg R.A.; Mills E., Bloomfield J., (2002): Increased crop damage in the U.S. from excess precipitation under climate change, Global Environ Change 12, 197-202.

SADS (2030): The Sustainable Agricultural Development Strategy towards 2030. Agricultural Research \& Development Council (ARDC).

Smith, R.D., and P.R. Gent, (2002): Reference Manual for the Parallel Ocean Program (POP), Ocean Component of the Community Climate System Model (CCSM2.0 and 3.0). Technical Report LA-UR-022484, Los Alamos National Laboratory, Los Alamos, NM.

Verseghy, D.L., N.A. McFarlane, and M. Lazare, (1993): A Canadian land surface scheme for GCMs: II. Vegetation model and coupled runs. Int. J. Climatol., 13, 347-370.

World Bank Report, (2007): Assessing the Impact of Climate on Crop Water Needs in Egypt. Global Environment Facility. Policy Research Working Paper, World Bank, WPS4293, 35 pp.

Xu, Y., Y. Luo and Z. C. Zhao, (2005): Detection of climate change in the $20^{\text {th }}$ century by the NCC T63. Acta Meteorol. Sin., Special Report on Climate Change, 4, 1-15.

Yones M. S.; Abd ElRahman H. A.; Abou Hadid A. F.; Arafat S. M. and Dahi, H. F. (2011): Heat Unit Requirements for Development of the Pink Bollworm Pectinophora gossypiella (Saund.), Egypt. Acad. J. biolog. Sci., 4 (1) $115-122$. 


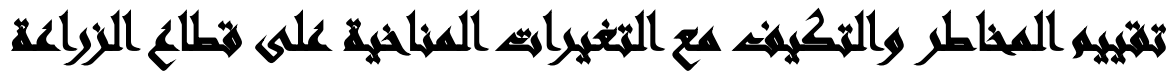

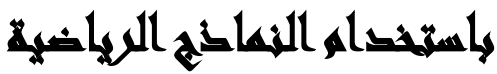

[1]

محمد غريب المالكي(')- محمد مجدي عبد الوهاب(ץ)- كريستوفز رويين براينت(ץ)

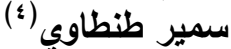


مونترياال، كيبيك، كندا ع) جهاز شئون البيئة، القاهرة

\section{enarill}

تمنل الزراعة قضية اقتصادية كبرى بالنسبة لمصر، فهي مصدر أساسي للغذاء، والتجارة

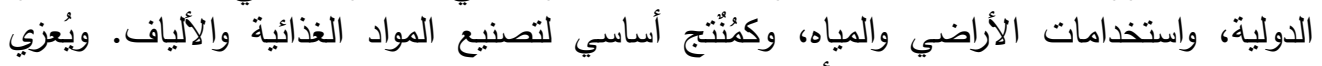

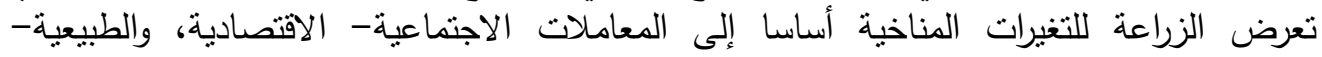



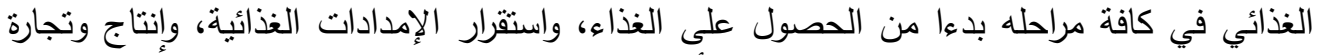

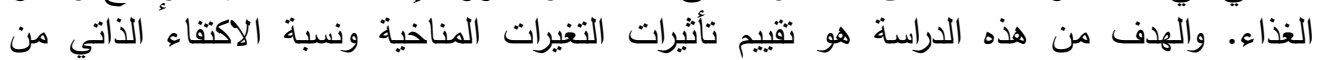



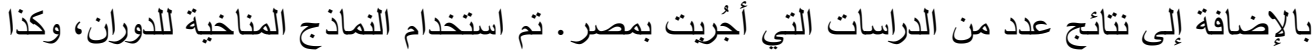

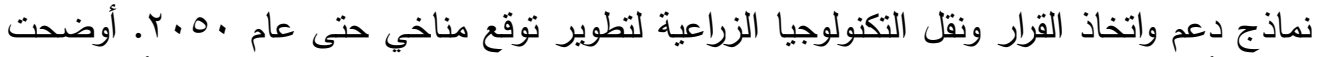

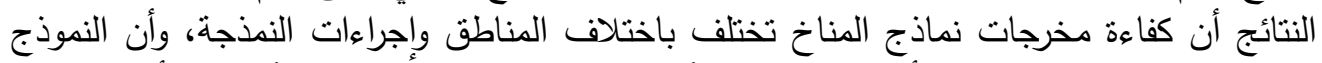

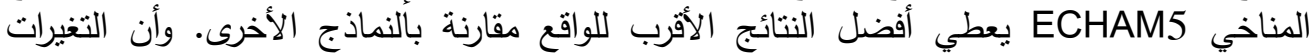
المناخية يمكن أن تساهم في الإسراع من أزمة الأمن الغذائي التي تعاني منها مصر بالفي بالفعل. 